\title{
KAJIAN EKONOMI DAN PENYERAPAN TENAGA KERJA PADA USAHATANI TEMBAKAU POLA KEMITRAAN DI KABUPATEN LOMBOK TIMUR
}

\author{
ECONOMIC STUDY AND LABOR FORCE ABSORPTION ON \\ PARTNERSHIP TOBACCO FARM IN EAST LOMBOK DISTRICT
}

\author{
Wuryantoro dan Candra Ayu
}

Program Studi Agribisnis Fakultas Pertanian Universitas Mataram

\begin{abstract}
ABSTRAK
Kabupaten Lombok Timur merupakan sentra produksi tembakau di NTB. Hal ini dikarenakan Lombok Timur memiliki daya dukung relatif lebih tinggi dibandingkan dengan daerah lain di NTB, serta banyaknya jumlah perusahaan yang terlibat dalam melakukan pembinaan pada komoditi ini. Penelitian ini ditujukan; (1) untuk mengetahui dampak kemitraan terhadap kelayakan dan penyerapan tenaga kerja pada usahatani tembakau, (2) untuk mengetahui pola kemitraan atau binaan yang terbentuk antara perusahaan dan petani tembakau. Metode yang digunakan dalam penelitian ini adalah metode deskriptif, sedangkan pengumpulan data dengan teknik survei dengan mewawancarai 20 petani responden. Hasil penelitian menunjukkan, bahwa keuntungan yang diperoleh petani sebesar Rp 25220734 per Ha, dengan R/C-ratio usahatani 1,77 serta tingkat pengembalian modal (B/C-ratio) sebesar $76 \%$, ini berartai secara finansial usahatanI tembakau virgina sangat layak dikembangkan. Selain itu, hasil penelitan juga menunjukkan bahwa usahatani tembakau virginia mampu menyerap tenaga kerja yang sangat besar yakni sebesar 557 HKO per musim per Ha. Selain itu, hasil penelitian juga menunjukkan bahwa respon petani terhadap pola kemitraan yang dikembangkan oleh perusahaan cukup baik, terutama terhadap aspek budidaya dan pemasaran. Pola atau model kemitraan antara petani dan perusahaan pada usahatani virginia adalah pola dagang umum. Petani tembakau virgina yang bermitra dengan perusahaan mampu mengelola usahatani secara efisien serta memperoleh keuntungan yang cukup.
\end{abstract}

Kata Kunci: kelayakan, penyerapan tenaga kerja, kemitraan 


\begin{abstract}
East Lombok Regency is the center of tobacco production in West Nusa Tenggara. This is because East Lombok has a relatively higher carrying capacity compared to other regions in West Nusa Tenggara as well as the large number of companies involved in providing guidance for this commodity. The aims of this research were; (1) to analyze the feasibility and labor force absorption of the partnership tobacco farming, (2) to determine the pattern of partnerships formed between companies and tobacco farmers. The method used in this research is descriptive method, while data collection using survey techniques by interviewing 20 respondent of farmers. The results showed that the profits obtained by farmers were Rp. 25220734 per hectare, with a farming $R / C$ ratio of 1.77 and a return on capital (B/C-ratio) of $76 \%$, this means that financially virgina tobacco farming is very feasible to be developed. In addition, the research results also show that virginia tobacco farming is able to absorb a very large labor force, namely $557 \mathrm{HKO}$ per season per hectare. In addition, the results also showed that the response of farmers to the partnership pattern developed by the company was quite good, especially in the aspects of cultivation and marketing. The pattern or model of partnership between farmers and companies in virginia farming is a common trading pattern. Virgina tobacco farmers who partner with the company are able to manage their farming efficiently and get sufficient profits.
\end{abstract}

Key words : feasibility, absorption labor force, partnership

\title{
PENDAHULUAN
}

Usahatani tembakau virginia di Lombok merupakan salah satu usahatani sektor perkebunan yang cukup penting di Provinsi Nusa Tenggara Barat, hal ini disebabkan karena produksi tembakau virginia asal Lombok memiliki kualitas yang cukup bagus dan mampu bersaing di pasaran nasional maupun internasional. Dibandingkan dengan Kabupaten lain di Propinsi Nusa Tenggara Barat, Kabupaten Lombok Timur mempunyai areal tanam terluas sehingga merupakan sentra produksi untuk usahatani tembakau virginia. Hal ini disebabkan karena Kabupaten Lombok Timur memilki daya dukung relatif lebih tinggi dibandingkan dengan daerah lain di NTB dalam mengusahakan tanaman tembakau virginia, terutama keadaan alam, sistem budidaya serta keberadaan perusahaan pemasok tembakau Virginia. Tabel berikut menunjukkan luas areal dan produksi tembakau di Pulau Lombok. 
Tabel 1. Luas Areal dan Jumlah Produksi Tembakau Virginia di Pulau Lombok Tahun 2017

\begin{tabular}{|l|r|r|}
\hline Kabupaten/Kotamadya & Luas (ha) & Produksi (ton) \\
\hline Lombok Barat & 64,8 & 97,2 \\
\hline Lombok Tengah & $7.780,5$ & $11.439,8$ \\
\hline Lombok Timur & $12.731,1$ & $21.642,9$ \\
\hline Lombok Utara & 139,8 & 235,7 \\
\hline
\end{tabular}

Sumber: Dinas Perkebunan Lombok Barat Tahun 2017

Perkembangan usahatani di Pulau Lombok, khususnya di Lombok Timur tidak terlepas adanya keterlibatan perusahaan dalam pembinaan petani tembakau. Sejalan dengan penerapan pola binaan tersebut pemerintah daerah lebih memberi peluang kepada pihak swasta agar usahatani tembakau dapat tumbuh dan berkembang secara sehat dan dinamis. Hal tersebut tercermin dalam surat keputusan pemerintah daerah nomor: 219/KPTS/ KB/1996 yang memberlakukan sistem pembinaan dengan pola kemitraan terhadap petani tembakau melalui Program Intensifikasi Tembakau Virginia (ITV) yang melibatkan perusahaan tembakau swasta. (Dinas Perkebunan NTB, 2017). Hingga saat ini Program ITV dengan pola kemitraan di Kabupaten Lombok berkembang sangat positif, hal ini terlihat makin banyaknya jumlah perusahaan yang terlibat dalam melakukan pembinaan. Perusahaan-perusahaan yang dimaksud adalah PT. Djarum, PT. Anugrah Alam Abadi, PT. Mangli Jaya Raya, PT. Cakrawala pada tahun 1987 serta PT. Tresno Bentoel, PT. Trisno Adi, PT. HM. Sampoerna, PT. Sadhana Arifnusa, PT. Gelora Djaja dan PT Export Leaf Indonesia (ELI).

Berdasarkan uraian di atas maka penelitian ini ditujukan: (1) untuk menganalisis kelayakan usaha dan penyerapan tenaga kerja pada usahatani tembakau virginia yang bermitra dengan perusahaan, (2) untuk mengetahui pola kemitraan atau binaan yang terbentuk antara perusahaan dan petani tembakau.

\section{METODOLOGI PENELITIAN}

\section{Metode dan Teknik Penelitian}

Penelitian ini menggunakan metode deskriptif yang bersifat menggali permasalahan (explorative research) yang ditujukan pada penemuan fakta berdasarkan gejala-gejala faktual tentang perilaku suatu kelompok atau masyarakat dengan jalan mengumpulkan data, menyusun, mengolah, menganalisa, mendeskripsikan dan menarik kesimpulan. Pengumpulan data dilakukan dengan teknik survei yaitu dengan mengadakan wawancara mendalam (in-depth interview) dengan responden, tokoh masyarakat dengan berpedoman pada daftar pertanyaan (quesioner) yang telah didesain sebelumnya (Nazir, 2014).

\section{Penetapan Lokasi dan Sampel Penelitian}

Daerah penelitian ditentukan dengan menggunakan metode secara sengaja (purposive method) dimana daerah lokasi penelitian adalah Kabupaten Lombok 
Timur. Dalam penelitian ini, Kecamatan Jerowaru sebagai daerah lokasi pengambilan sampel petani tembakau virginia. Hal ini karena di Kecamatan Jerowaru merupakan kecamatan yang mempunyai luas tanam tembakau virgina terluas. Jumlah petani yang dijadikan responden ditentukan secara quota sampling yaitu sebanyak 20 petani.

\section{Analisis Data}

Untuk menjawab tujuan dan permasalahan yang ada, data yang terkumpul dianalisis secara kuantitatif dan kulatatif yang selanjutnya diinterpretasikan. Lebih detailnya, model analisis yang digunakan adalah sebagai berikut:

1. Untuk mengetahui untuk persepsi, sikap, dan adopsi petani terhadap progam ITV serta pengaruh inovasi terhadap perbaikkan budidaya (pengelolaan) usahatani tembakau, seperti kesusaian penggunaan input (faktor produksi) dengan rekomendasi digunakan alat analisis deskripsi

2. Analisis pendapatan usaha tani tembakau virginia dilakukan dengan menggunakan rumus (Downey dan Erickson, 1985), dengan persamaan:

$$
\mathbf{I}=\sum(\mathbf{Y} \text {. Py })-\sum(\mathbf{X i} \text {. Pxi })
$$

Dimana:

$$
\begin{aligned}
& \text { I = Pendapatan }(\mathrm{Rp} / \mathrm{hektar} / \mathrm{musim}) \\
& \mathrm{Y}=\text { Output (yield) }(\mathrm{kg} / \mathrm{hektar} / \mathrm{musim}) \\
& \text { Py = Harga output (price yield) }(\mathrm{Rp} / \mathrm{kg}) \\
& \text { Xi.P Xi = Harga setiap jenis input ke i } \quad(\mathrm{i}=1,2,3, \ldots \ldots, \mathrm{n})(\mathrm{Rp} / \mathrm{hektar})
\end{aligned}
$$

3. Untuk mengetahui kelayakan usahatani tembakau, atau kelayakan usaha tani digunakan analisis Return Cost Ratio (R/C ratio) dan Benefit-Cost Ratio (B/C ratio) (Suratiyah K., 2015). R/C ratio adalah perbandingan (nisbah) antara penerimaan dan biaya. Secara matematik dapat dituliskan sebagai berikut:

$$
R / C=\begin{gathered}
T R \\
-----
\end{gathered}
$$

Sedangkan $\mathrm{B} / \mathrm{C}$ ratio perbandingan antara benfit (keuntungan bersih) dengan biaya produksi, yang dapat diformulasikan sebagai berikut:

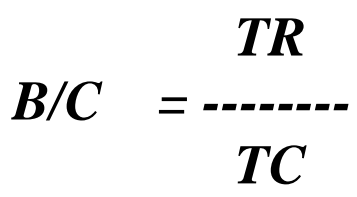

Dimana:

$\mathrm{R}=$ Revenue (nilai produksi atau penerimaan

$\mathrm{B}=$ Benefit (keunutngan)

$\mathrm{C}=$ Cost (biaya produksi)

$\mathrm{TR}=$ Total revenue (penerimaan)

$\mathrm{TC}=$ Total Cost (total biaya produksi) 
4. Untuk menghitung curahan waktu kerja ibu rumahtangga dengan analisis Mandyas; yakni $\mathrm{HKO}=(\mathrm{t} \times \mathrm{h} \times \mathrm{j}) / 6$ (keterangan: $\mathrm{HKO}=$ Hari Kerja Orang, $\mathrm{t}=$ jumlah tenaga kerja yang digunakan, $h=$ jumlah hari kerja, $\mathrm{j}=$ jumlah jam kerja per hari dan 6 = angka standar jumlah jam kerja manusia per hari) (Sadyadharma, 1984).

\section{HASIL DAN PEMBAHASAN}

\section{Analisis Biaya Produksi dan Pendapatan Usahatani Tembakau Virginia}

Analisis pendapatan mempunyai kegunaan bagi petani maupun bagi pemilik faktor produksi. Ada dua tujuan utama dari analisis pendapatan yaitu:

1. Menggambarkan keadaan sekarang suatu kegiatan usahatani.

2. Menggambarkan keadaan yang akan datang dari perencanaan atau tindakan.

Analisis Biaya Usaha Tani Tembakau di Kabupeten Lombok Timur Dalam penelitian ini dilakukan analisis biaya dan pendapatan yang diperoleh petani dalam kegiatan usaha tani tembakau dalam satu kali proses produksi. Biaya usaha tani yang diperhitungkan adalah keseluruhan biaya yang dikorbankan petani dalam kegiatan usaha tani. Pendapatan bersih adalah selisih antara total nilai produksi dengan total biaya yang dikeluarkan dalam proses produksi. Komponen terbesar pembiayaan usaha tani tembakau adalah untuk tenaga kerja baik waktu pembibitan, persiapan lahan, penanaman dan pemeliharaan sampai tahap panen dan pascapanen. Tabel berikut menunjukkan hasil analisis biaya produksi usahatani tembakau Virginia yan dikeluarkan petani yang bermitra dengan perusahaan.

Tabel 2. Analisa Biaya Produksi dan Pendapata Usahatani Tembakau Virginia Petani per Ha Tahun 2019

\begin{tabular}{|c|l|c|c|}
\hline No. & Jenis biaya & \multicolumn{2}{|c|}{ Petani Mitra } \\
\hline & & Volume & Nilai (Rp) \\
\hline 1. & Benih/bibit & - & 450917 \\
& Plastik dan bambu pembenihan & & 525000 \\
\hline 2. & Pupuk (Kg): & & 1890000 \\
& $-\quad$ KNO3 & 67,5 & 168750 \\
& $-\quad$ Urea & 169,8 & 510000 \\
\hline 3. & $-\quad$ Fertila & 2,95 & 285500 \\
& Pestisida/obat-obatan & 1 & 130988 \\
& - Vitaco (liter) & 4,5 & 675000 \\
& - Dupont (kg) & 0,9 & 56000 \\
\hline & - Antracol (kg) & & $4692155(14 \%)$ \\
\hline 4. & Sub Total & 557 & $24315553(74 \%)$ \\
\hline 5. & Penaga kerja (HKO) & - & 750000 \\
\hline 6. & Biaya bahan bakar & & $4990000(15 \%)$ \\
\hline & Total Biaya Produksi & & 32833374 \\
\hline
\end{tabular}

Sumber : Data Primer Diolah 
Tabel 2 di atas menunjukkan besarnya biaya produksi yang dikeluarkan oleh petani dalam satu kali proses produksi pada usahatani tembakau virginia. Biaya produksi ini meliputi, biaya Variabel (biaya saprodi, biaya tenaga kerja), biaya tetap (biaya penyusutan alat, dan biaya sewa tanah), dan biaya lain-lain.

Hasil analisis (Tabel 2) menunjukkan total biaya produksi yang harus dikeluarkan petani untuk membiayai usahatani tembakau dalam satu kali musim tanam cukup besar, yakni sebanyak Rp 32833374 per musim tanam per Ha. Dari total tersebut, jenis biaya yang paling besar dikeluarkan oleh petani adalah biaya tenaga kerja yakni sebesar Rp 24315553 per Ha atau sekitar $70 \%$ dari total biaya yang digunakan untuk usahatani tembakau. Sedangkan biaya yang harus dikeluarkan petani untuk pengadaan bahan bakar dana sarana produksi (benih, pupuk, dan obatobatan) yaitu berturu-turut Rp 4990000 atau $15 \%$ dan sebesar Rp 4692155 atau $14 \%$ dari total biaya produksi dalam $1 \mathrm{Ha}$ per musim tanam. Besarnya biaya tenaga kerja tersebut mengindikasikan bahwa usahatani tembakau dalam pengelolaannya memerlukan perawatan dan pengelolaan yang sangat intensif mulai dari pembibitan, pengolahan lahan sampai pengovenan (pengomprongan).

\section{Anasisis Pendapatan dan Kelayakan Usahatani Tembakau Virginia}

Besarnya tingkat produksi, pendapatan dan efisiensi usaha yang dihasilkan petani yang bermitra dengan perusahaan di Lombok Timur, disajikan pada tabel berikut.

Tabel 3. Tingkat Produksi, Pendapatan dan Efisiensis Usahatani Tembakau Kemitraan di Lombok Timur 2019

\begin{tabular}{|c|l|c|c|}
\hline No. & \multicolumn{1}{|c|}{ U r i a n } & Volume & Nilai \\
\hline 1. & Produksi (Kw -Daun Kering) & 17,86 & \\
\hline 2. & Harga (Rp) & 3250510 & \\
\hline 3. & Nilai Produksi (Rp) & & 58054108 \\
\hline 4. & Total Biaya (Rp) & & 32833374 \\
\hline 5. & Pendapatan (Rp) & & 25220734 \\
\hline 6. & R/C -Ratio & & 1,77 \\
\hline 7. & B/C- ratio (\%) & $0,76(76 \%)$ \\
\hline
\end{tabular}

Sumber: Data primer diolah

Dari tabel di atas diketahui bahwa produksi tembakau daun krosok yang dihasilkan petani yang bermitra dengan perusahaan cukup tinggi yaitu sebanyak 17,86 Kw dengan harga rata-rata Rp 3250 510,- per kwintal. Dengan harga tersebut penerimaan petani dari usahatani Tembakau Virginia sebesar Rp 58054 108,-. Total biaya yang dikeluarkan petani adalah Rp 32833 374,- dengan demikian pendapatan yang diterima petani adalah sebesar Rp 25220 734,- per Ha per musim tanam. Selanjutnya dari sisi efisiensi dan kelayakan usaha, usahatani Tembakau Virginia sangat layak untuk diusahakan. Dari tabel di atas diketahui $\mathrm{R} / \mathrm{C}$ - ratio yang dihasilkan dari usahatani tembakau adalah 1,77. ini berarti bahwa setiap Rp 1 korbanan (biaya produksi) mampu menghasilkan nilai produksi atau penerimaan sebesar Rp 1,77. Dari sisi produktivitas modal, hasil penelitian menunjukkan bahwa usahatani Tembakau Virginia mampu memberikan tingkat pengembalian modal 
sebesar $76 \%$, sementara itu jika modal yang ada investasikan dalam bentuk deposito tingkat pengembalian yang diterima hanya sebesar $6 \%$ per tahun. Kenyataan tersebut menunjukkan bahwa tingkat pengembalian modal yang dihasilkan dari usahatani Tembakau Virginia jauh lebih besar dibandingkan dengan tingkat suku bunga deposito yang ditawarkan oleh bank.

\section{Penyerapan Tenaga Kerja}

Sektor pertanian memegang peranan penting dalam perekonomian. Besarnya kontribusi sektor pertanian terhadap perekonomian nasional tersebut diindikasikan juga dengan besarnya penyerapan tenaga kerja. Secara sederhana penyerapan tenaga kerja berarti jumlah tenaga kerja yang mampu diserap oleh sektor perekonomian. Sedangkan penyerapan tenaga kerja sektor pertanian berarti jumlah tenaga kerja yang mampu diserap oleh sektor pertanian

Hasil penelitian terhadap kemampuan usahatani Tembakau Virgina dalam menyeraptenaga kerja di Kabapaten Lombok Timur tergambar pada Tabel 4.3. Pada tabel tersebut diketahui bahwa jumlah tenaga kerja yang diperlukan dalam usahatani tembakau mulai dari pembibitan sampai pengovenan dan tembakau kering siap dijual adalah sebesar 557 HKO per musim per Ha. Ini berarti bahwa usahatani tembakau virginia mampu menyerap tenaga kerja yang sangat besar. Tingginya serapan tenaga kerja pada usahatani tembakau Virginia disebabkan karena banyaknya tahapan kegiatan pada usahatani Tembakau Virginia yaitu mulai dari pembibitan, persiapan lahan, pengolahan lahan, penanaman, pemeliharaan, panen dan pasca panen. Selain itu besarnya tenaga kerja yang mampu diserap oleh kegiatan usahatani tembakau tersebut terpilah pada dua kegiatan utama, yaitu kegiatan budidaya dan kegiatan agroindustri (pasca panen). Tenaga kerja yang diserap pada kegiatan pasca panen mulai dari penyotiran daun, pengovenan dan pengemasan produk adalah sebesar $227 \mathrm{HKO}$ atau sekitar $40 \%$. Jika dibandingkan dengan serapan tenaga kerja sub sektor tanaman pangan, maka daya serap usahatani tembakau terhadap tenaga kerja jauh lebih besar. Dimana usahatani jagung hanya membutuhkan atau menyerap tenaga kerja sebesar 52 HKO per musim per Ha (Wuryantoro, 2018) sedangkan usahatani padi menyerap tenaga kerja sebesar 87 HKO per musim per Ha (Astuti Damayanti, N, 2018)

\section{Pola dan Respon Petani Terhadap Kemitraan}

Secara umum, kemitraan usaha adalah kerja sama antara dua pihak dengan hak dan kewajiban yang setara dan saling menguntungkan. Hubungan kemitraan usaha umumnya dilakukan antara dua pihak yang memiliki posisi sepadan dalam hal tawarmenawar (bargaining position). Kemitraan usaha bersama bertujuan untuk meningkatkan pendapatan, kesinambungan usaha, jaminan suplai jumlah, kualitas produksi, meningkatkan kualitas kelompok mitra, peningkatan usaha, dalam rangka menumbuhkan dan meningkatkan kemampuan usaha kelompok mitra yang mandiri (Martodireso dkk, 2002).

Dari hasil penelitian diperoleh gambaran bahwa pola atau model kemitraan oleh perusahaan di Lombok Timur adalah pola dagang umum. Pola dagang umum merupakan pola kemitraan mitra usaha yang memasarkan hasil dengan kelompok usaha yang menyuplai kebutuhan yang diperlukan oleh perusahaan. Pola kemitraan ini memerlukan struktur pendanaan yang kuat dari pihak yang bermitra, baik mitra usaha besar maupun mitra usaha kecil. Sifat dari kemitraan ini pada dasarnya adalah membeli dan menjual terhadap produk yang dimitrakan. 
Perusahaan yang menjadi mitra usahatani menyediakan segala kebutuhan petani, mulai dari modal, bibit, pupuk, petugas lapangan, sampai pada penjualan. Model kemitraan memberikan beberapa manfaat bagi para petani, antara lain.

1. Produktivitas akan meningkatkan kualitas maupun kuantitas hasil kemitraan.

2. Efisiensi kemitraan dapat menghemat waktu dan tenaga dalam pelaksanaannya.

3. Jaminan kualitas, kuantitas dan kontinuitas kualitas, kuantitas dan kontinuitas sangat erat kaitannya dengan efisiensi dan produktivitas sebagai pendorong kemitraan.

4. Resiko kemitraan dapat mengurangi resiko sehingga semua pihak kemitraan dapat menanggung resiko.

5. Ketahanan sosial kemitraan sebagai bentuk upaya pemberdayaan.

Kelebihan lain yang diperoleh oleh petani mitra dari perusahaan adalah diberikan tenaga PPL (Penyuluh Pertanian Lapangan) yang memberikan bantuan dalam penanaman sampai kepada penjualan hasil kepada perusahaan. Petani mitra tidak repot dalam memasarkan hasil serta dijamin kesesuaian harga dengan modal yang dikeluarkan. Adanya PPL dari perusahaan menjamin kualitas hasil panen petani mitra, sehingga kerugian dan gagal panen dapat diminimalisir. Berbeda dengan petani non mitra yang tidak memiliki PPL secara khusus serta tidak ada tempat yang pasti untuk menjual hasil panen.

Keberadaan perusahaan mitra bagi petani tembakau sangat menguntungkan baik dari faktor produksi maupun pendapatan. Petani mitra yang menjadi binaan perusahaan tidak terlalu sibuk dalam menangani usahatani tembakau virginia, karena perusahaan telah menyiapkan segala faslitas yang dibutuhkan. Hasil panen juga dijamin dengan kualitas yang baik dan dibeli oleh perusahaan sesuai dengan standar grade yang ditetapkan dengan tidak merugikan petani.

Hasil peneltian juga menunjukkan bahwa respon petani terhadap kemitraan yang dilakukan dengan perusahaan dapat dikelompokkan menjadi empat aspek, yaitu meliputi aspek teknik budidaya, aspek bantuan saprodi, aspek ekonomi (bantuan modal), dan aspek pemasaran. Pada umumnya petani merespon sangat baik terhadap pola kemitraan (binaan yang dikembangkan oleh perusahaan, kecuali pada aspek pemasaran. Dalam aspek teknis, bimbingan teknik budidaya yang dilaksanakan perusahaan dinilai baik oleh petani. Seluruh responden mengakui bahwa pembinaan teknis selama ini telah memberikan manfaat yang sangat berarti dalam menambah pengetahuan dan keterampilannya dalam berusahatani, terutama berkaitan dengan kegiatan pengolahan tanah, pengaturan jarak tanam dan pemberian dosis pupuk untuk tembakau virginia. Petani juga bersikap positif (memberikan penilaian baik) terhadap bantuan saprodi yang diberikan oleh perusahaan, terutama berkaitan dengan jumlah sarana produksi (terutama benih dan pupuk) dan ketepatan waktu distribusi sudah sesuai dengan harapan petani. Meskipun bantuan tersebut sifatnya pinjaman, yakni akan dibayar setelah produksi dibeli oleh perusahaan. Sementara itu sikap petani berkaitan dengan pelayanan bantuan modal petani bersikap tidak baik. Tidak seperti beberapa tahun sebelumnya, saat ini perusahaan tidak memberi bantuan dana kepada petani mitra, sehingga petani harus mempunyai modal sediri yang cukup untuk membiayai seluruh kegiatan usahataninya. 


\section{KESIMPULAN DAN SARAN}

\section{Kesimpulan}

1. Petani Tembakau Virgina yang bermitra dengan perusahaan mampu mengelola usahatani secara efisien serta memperoleh keuntungan yang cukup. Hasil penelitian menunjukkan, bahwa keuntungan yang diperoleh petani sebesar Rp 25 220734 per $\mathrm{Ha}$, dengan R/C-ratio usahatani 1,77 serta tingkat pengembalian modal (B/C-ratio) sebesar $76 \%$.

2. Pola atau model kemitraan antara petani dan perusahaan pada usahatani virginia di Lombok Timur adalah pola dagang umum. Pola dagang umum merupakan pola kemitraan mitra usaha yang memasarkan hasil dengan kelompok usaha yang menyuplai kebutuhan yang diperlukan oleh perusahaan.

\section{Saran}

Guna meningkatkan keuntungan yang diperoleh petani tembakau virginia perusahaan diharapkan mau memberikan pendampingan secara konsisten terhadap petani, terutama pada kegiatan pengovenan, sehingga diperoleh daun kerosok dengan kualitas sesuai dengan yang diharapkan perusahaan.

\section{DAFTAR PUSTAKA}

Astuti Damayanti, N, 2018. Efisiensi Alokatif Penggunaan Sarana Produksu Pada Program UPSUS Padi di Kecamatan Sandubaya Kota Mataram. Skripsi. Fakultas Pertanian UNRAM.

BPS Propinsi NTB, 20017. Lombok Timur Dalam Angka Tahun 20173. Mataram

Dinas Perkebunan NTB, 2017. Tembakau Virginia Komoditi Andalan Lombok Timur. Dinas Perkebunan Dati I NB. Mataram.

Downey, W.D. dan S.P. Erickson. 1985. Manajemen Agribisnis. Dialih-bahasan oleh Rochidayat, Gonda S, dan Alfonsus. Penerbit Erlangga. Jakarta. 516 p.

Martodireso, Sudadi dan Widada Agus Suryanto. 2002. Agribisnis Kemitraan Usaha Bersama (Upaya Peningkatan Kesejahteraan Petani). Kanisius.Yogyakarta.

Nazir, M., 2014. Metode Penelitian. Ghalia Indonesia. Jakarta. 622 h.

Sunarso, 2002. Kiat Sukses Perusahaan Swasta dalam Pengembangan Agribisinis di NTB. Makalah pada Lokarya Pengembangan Kurikulum Program Studi Agribisnis. Fakultas Pertanian Unram.

Suratiyah, Ken., 2015. Ilmu Usahatani. Penerbit: Penebar Swadaya. Jakarta

Wuryantoro, 2018. Studi Kinerja Ekonomi dan Efisiensi Alokatif Penggunaan Faktor Produksi Pada Program Upsus Jagung di Kabupaten Sumbawa. Laporan Penelitian. Fakultas Pertanian UNRAM. 